\title{
Plants Colonizing Disturbed AReas in FIFTEEN ROCKY MOUNTAIN ENVIRONMENTS-- WEEDS AND RECLAMATION CANDIDATES
}

\author{
T. WEAVER $\diamond$ D. GUSTAFSON $\bullet$ J. LICHTHARDT \\ BIOLOGY DEPARTMENT $\bullet$ MONTANA STATE UNIVERSITY \\ BOZEMAN
}

$\checkmark$ ABSTRACT

We list plants which are commonly established in road cuts in fifteen major Northern Rocky Mountain environmental types. We expect them to establish well on new disturbances in the same environmental types. Thus, our list of natives can be used to choose plants for reintroduction of natives to construction sites and other disturbed areas; additional data on life form, aggressiveness (cover), and altitudinal distribution will be useful for choosing among seeding candidates and selecting seed sources for the reseeding. And, our list of establishing exotics will identify the weeds most likely to colonize a site, their aggressiveness on disturbed sites, and their capacity to enter adjacent undisturbed vegetation; this list will caution against introduction of certain exotics (e.g. Poa pratensis, Phleum pratense, and most Trifoliums-- as well as noxious weeds) and will be the basis for plans to control locally noxious exotics early and aggressively.

\section{$\bullet \quad$ INTRODUCTION}

Man disturbs the vegetation of national parks both locally (e.g. through construction and trampling) and more broadly (e.g. 1984 fire, pollution, and introduction of exotics).

Since national parks are maintained as reserves for native communities, rigorous reclamation with native species must follow significant disturbances. Our paper has two relevant objectives. 1) We list native plants most suitable for reseeding construction sites in major environmental zones (HT's); these lists will help restoration engineers to choose appropriate plants and to develop the seed sources necessary to install them.

2) We list the exotics most likely to be troublesome in HT's; these exotics can be used to anticipate weed problems and thus to facilitate control.

\section{$\checkmark \quad$ METHODS}

Sites were sampled in sixteen environmental types which broadly represent the vegetation of the northern Rocky Mountains in order to determine: 1) what native plants invade disturbed sites and might be useful for revegetation and 2) what exotic plants invade similar sites and whether they spread into native vegetation (early or late seral). We sampled six to eleven sites in each type (Table 1). For convenience, we refer to a code formed from the first two letters of the genus and species of plants dominating the over and understories in Table 1. The environmental types which are named for late seral vegetation that occupies them included: dry grasslands (BOGR/ STCO and AGSP/ BOGR), moist grasslands (FESC/ FEID), sagebrush-lands (ARAR/ FEID and ARTRvas/ FEID), warm dry forests (PSME/ SYAL and PSME/ PHMA), warm moist forests (POTR/ CARU, THPL/ OPHO, TSHE/ CLUN, ABLA/ CLUN), cool forests (ABLA/ XETE, ABLA/ ARCO, and ABLA/VASC), mountain meadows (FEID/ AGCA), and alpine (DECE/ 
CAREX). These environmental types (HTs) are described by Daubenmire (1968 \&1970), Mueggler and Stewart (1980), Pfister et al (1977), and Steele et al (1983). HT names, sample sizes, and the locations sampled are listed in Table 1.

In all fifteen HT's study sites were located along major roads for two reasons. First we wanted to compare native establishment on adjacent surfaces which were disturbed once versus continuously. And second, we wanted to compare exotic establishment on highly disturbed sites and adjacent undisturbed sites. Thus, at each site we sampled a block of five 'treatments' including continuously disturbed sites (road shoulder and adjacent ditch slopes), once disturbed sites (roadcuts and cleared right-of-ways) and undisturbed sites. The data used in this report come from roadcuts and undisturbed sub-sites only. By working on roadsides crossing through undisturbed vegetation, we insured good availability of native seeds on disturbed sites. And, by working with sites along highways, we insured good availability of exotic seeds on disturbed and undisturbed sites. The availability of exotic seeds on roadcuts and in undisturbed vegetation was further increased by dispersal of seeds from exotics established at roadsides. With guaranteed seed sources, the capacity of both natives and exotics to invade roadcuts was well tested.

Vegetation composition was recorded at each sub-site by measuring presence, frequency and cover of each species at each of approximately 800 plots (16 HTs x 5 disturbance types x 10 replications).

Presence was recorded by listing plant species present in a $1 \times 25 \mathrm{~m}$ plot representative of the zone and parallel to the road. We separately noted any other species present in adjacent and similar vegetation. While this paper is devoted primarily to species colonizing disturbed sites, presence in undisturbed vegetation was determined similarly and also reported in Tables $2 \& 3$.

Cover of a species was measured by recording the percent of seventy-five points covered by each species. The seventy-five points were located by lowering three pins into the vegetation in each meter of the plot's center line.

'Constancy' was calculated as the percent of sites in the environmental type in which the species occurred.

'Cover' was integrated over a type by averaging cover measurements across all sites only where a species occurred. We omitted unoccupied plots in these calculations to measure the success of species at sites where they occur. Cover values for the environmental zone as a whole can be calculated by multiplying the 'cover values' presented by the associated 'constancy value'; this will correct the cover value downward for sites at which the species did not occur (Tables 2 \& 3).

\section{$\checkmark \quad$ RESULTS}

To characterize a species, in Table 2 and 3, one reads the information on the line following it. Column 1 gives its name. Column 2 gives its life form $(T=$ tree, $S=$ shrub, $G=$ grass and $F=$ forb). Columns 3-17 compare its success in fifteen environments with measures of its constancy $(+=1-$ $9 \% \mathrm{~m} 1=10-19 \%, 2=20-29 \%$, etc) and its cover $(\mathrm{A}=0, \mathrm{~B}=<1 \%, \mathrm{C}=1-2 \%, \mathrm{D}=2-5 \%, \mathrm{E}=5-25 \%$, and $\mathrm{F}=25-100 \%$ ). Columns 3-17 also indicate that the species does $(*)$, or does $\operatorname{not}()$, appear in 'climax' vegetation of each environment. For example, the first line of Table 2 shows that Koeleria cristata is a grass (G) which seeds into disturbances in grasslands, shrublands and even subalpine fir (STCO through FESC and ABLA); its constancy varies among sites between 30 and $90 \%$, its cover ranges form 0 to $5 \%$, and excepting the Abies sites, it is also present in undisturbed vegetation $(*)$. These tables are designed, first, to show the distribution of individual species along the altitudinal gradient and, second, to group species with similar distributions.

Ordering the environmental types as on the altitudinal gradient demonstrates species response to the environmentally complex gradient and supports generation of hypotheses about controlling factors (Weaver 1979, 1980, 1994).

Distributions are treated at two levels. First, each table is divided into three segments: 1) those present species with broad un-interrupted distributions, 2) species with broad interrupted distributions, and 3) species with narrow distributions. This information is useful in the seed selection process. Second, species in each of these 
Table 1. Environmental types (HTs) in which colonization of natives and exotics was observed. Listing is in approximate attitudinal order.

Sample location

Stipa comata/ Bouteloua gracilis Agropyron spicatum/ Bouteloua gracilis

Festuca scabrella/ Festuca idahoensis

Note, below, two grasslands at

high altitude: FEID/AGCA \& DECE/CARX.

Artemisia arbuscula/ Festuca idahoensis Artemisia tridentata vaseyana/ Festuca idahoensis

Pseudotsuga menziesii/ Symphoricarpos albus

Pseudotsuga menziesii/ Physocarpus malvaceus

Populus tremuloides/Calamagrostis rubescens

Thuja plicata/ Oplopanax horridum

Tsuga heterophylla/ Clintonia uniflora

Abies lasiocarpa/ Clintonia uniflora

Abies lasiocarpa/ Xerophyllum tenax

Abies lasiocarpa/ Arnica cordifolia

Abies lasiocarpa/ Vaccinium scoparium

Festuca idahoensis/Agropryon caninum

Deschampsia caespitosa/Carex species

$\begin{array}{lcl}\text { (STCO/BOGR) } & 7 & \text { Broadwater MT } \\ \text { (AGSP/BOGR) } & 8 & \text { Broadwater MT } \\ \text { (FESC/FEID) } & 10 & \text { Glacier MT }\end{array}$

(ARAR/FEID)

(ARTRvas/FEID)

(PSME/SYAL)

(PSME/PHMA)

(POTR/CARU)

(THPL/OPHO)

(TSHE/CLUN)

(ABLA/CLUN

(ABLA/XETE)

(ABLA/ARCO)

(ABLA/VASC)

(FEID/AGCA)

(DECA/CASP)
Glacier MT

${ }^{1}$ The environmental types (HTs) listed are those of Pfister et al (1977), Meuggler and Stewart (1980) and Steele et al 1983. Type names are abbreviated with four-letter codes formed from the first two letters of the genus and species epithets.

groups are listed in order of increasing altitude of their lowest extensions. This information may be useful in choosing among alternative species for planting.

Fifteen major (widespread) Rocky Mountain environments are listed across the top of Tables 2 and 3. The HTs are listed in order of their appearance on the gradient from warm dry grasslands through cool moist forests to the alpine. The environments were recognized by their late seral vegetation and named after it (Daubenmire 1968,1968,1970; Pfister et al 1977; Mueggler and Stewart 1980, and Steele et al 1983). They included arid grasslands Stipa/

Bouteloua and Agropyron/Bouteloua, shrublands Artemisia arbuscula/Festuca and $A$. tridentatal Festuca, warm dry grasslands Festuca scabrella/ F. idahoensis, warm dry forests Pseudotsugal Symphoricarpus and Pseudotsuga/Physocarpus, warm moist forests Tsuga/Clintonia, and Abies/Clintonia, cool moist forests Abies/Xerophyllum, Abies/Arnica, and Abies/Vaccinium, mountain meadows Festuca/ Agropyron, and alpine Deschampsia/Carex. Climatic differences among the environments are primarily responsible for the differences in vegetation types. Climatic conditions and productivities of these ecosystems are discussed by Weaver (1980, 1994). Differences among the soils of these types were summarized by Weaver (1979).

In this paper, roadcuts (facing the road) represent disturbed sites and adjacent undisturbed sites serve as late seral controls. Species listed down the left side of Tables 2 and 3 commonly appeared on disturbed sites in at least one environmental type. The importance of each species on disturbed sites in each environment is described by a table entry following the species name and under the environment name. The presence of each species in late seral vegetation on paired sites is indicated by an asterisk. A 'common species' was arbitrarily defined as one occurring on at least half the sites sampled in one environmental type. The 'importance' of a species is indicated by it's probability of occurrence ( = constancy, $+>0$, $1>10 \%, 2>20 \%$, etc) and it's average cover (C> $1 \%, \mathrm{D}>2 \%, \mathrm{E}>5 \%, \mathrm{~F}>25 \%)$ on sites where it occurred. 


\section{$-\quad$ DISTRIBUTIONS}

Natives. Natives show three distribution types (Table 2). The first segment of Table 2 lists species which have broad distributions. Due to ecotypic differentiation, different seed sources should probably be used for high and low altitude sites within the range of the species. The second segment includes species which have broad, but interrupted ranges. On the attitudinal gradient these first appear in low sites (sage, fescue, or douglas fir environments) skip some forest environments, and reappear in open vegetation at higher altitude Abies/Arnica, Abies/Vaccinium, or Festuca/ Agropyron. Since the populations are apparently separated, it seems even more likely that they are adapted to different conditions (e.g. temperature) so different seed sources may be appropriate. The third segment lists species which have such narrow distributions (1-3 similar environmental types) that ecotypic differentiation is probably slight.

Exotics. Exotics demonstrate the same distributional patterns as the natives. The first segment in Table 3 lists species with broad distributions. One wonders whether adaptation in these recently introduced and widespread species is accomplished through ecotypic differentiation or developmental flexibility. The second segment lists species with broad distributions interrupted by forest environments. The first three species range lower than do bimodal natives. The upper outposts of all these species seem less well developed than native populations in the same environmental types. If so, two explanations, not mutually exclusive, are offered. Despite roadside locations, exotics introduced at low altitude have been poorly distributed to higher sites. Or, exotics from open sites in warm dry climates are just now adapting to fill open dry sites in the relatively cool climates of higher sites.

\section{$\checkmark$ SPECIES FOR RESTORATION}

Choice of species. For a restoration project, we recommend native species which establish on at least half of the sites in the environmental type involved-- not just an occasional site which may be environmentally unique. In the Bouteloua environment, for example, the seven natives appearing on over half the disturbed sites are candidates for park plantings, the seven common exotics likely to grow well are ineligible in national parks, and the fifteen other species which appear with lower constancies are unlikely to establish $(\mathrm{p}>0.5)$. Data in the table allow the user to apply more stringent cut points, but since the table contains only species having a constancy over $50 \%$ in at least one environmental type, it cannot be used to make a complete list of species found on disturbed sites in any environmental type.

For a restoration project, one wants species with a high capacity to cover ground. The letter following the constancy numeral indicates cover on sites where the species established. One might want to use species which, in the past, covered over $5 \%$ (or $2 \%$ ) of the ground surface. For example, if one seeks, for Stipa/Bouteloua environments, species with at least $5 \%$ cover, only Stipa comata is acceptable. If one seeks species with at least $2 \%$ cover, Oryzopsis hymenoides is also acceptable. In using our data, note that our cover values were recorded with a point frame (see methods). Thus, they provide a repeatable measure, a measure comparable within a life form, a value lower than LAI (leaf area index), and a value lower than would be measured by the canopy cover method (Daubenmire 1968).

For a restoration project, one might also want information on the capacity of plants to spread. Plants spread vegetatively by branching above ground; tree-shrub designation (Table $1 \& 2$, column 2) describes this capacity qualitatively. Plants spread vegetatively near the ground surface by rhizomes or stolons. Relevant data for most of these plants appear in Dittberner and Olson (1983). One might also seek information on the spread of a species by seed; the spread of mixed mountain conifers is treated well by McCaughey et al (1986); We know of no comprehensive source on seed dispersal distances of Rocky Mountain grasses, forbs, and shrubs.

Seed sources. For genetic reasons, the best source of seed for any restoration project is from the site itself. This is approximated by seed collected from the site before disturbance, collected from adjacent sites (before or after disturbance), or coming from the seed bank. If the seed bank is to be useful, suffocation must be avoided by storing soils in thin layers and for only short periods (Dickie et al 1988, Munshower 1994). 
If the primary or supplemental seed source must come from off-site, the seed should ideally come from a nearby site having the same HT. There are two concerns. First, plants (ecotypes) coming from the same HT should be similarly adaptedunless they are collected at such a great distance (e.g. $100 \mathrm{~km}$ ) that global factors (eg the daylength regime) change (eg, Heslop-Harrison 1964). We expect this effect and encourage use of local material. Second one can argue that plants coming from different regions may be genetically distinct and new material should be excluded from every area, because it may dominate the gene pool existing on-site. We discount this effect when the seeded area is small relative to the area of adjacent native vegetation. In this case, adapted local genes should swamp out any deleterious introductions and we tentatively accept the introduction of beneficial (e.g. disease resistance) genes.

In the above context, seed gathering, rather than seed farming, is the preferred seed source. Plants introduced from nearby sites come from the same region and HT. In contrast, plants introduced from a seed farm environment will usually be selected for physiologies distinctly different with respect to such factors as temperature, possibly nutrients, within species competition, and between species competition.

Besides location, seed gatherers need collection dates. Collection times will vary with species, altitude, and season. The end-of-anthesis dates given by Dittberner and Olson (1983) or Schmidt and Lotan (1980) may help gatherers plan their calendars.

\section{$\checkmark$ MANAGEMENT OF EXotics}

Exotic management. With respect to the management of exotics, we have four concerns. First, exotics have been introduced along roadsides either accidentally or in plantings. The question arises, will they spread into adjacent native vegetation? Asterisks after matrix entries indicate that some spreading has occurred for all but three species Festuca pratensis, Trifolium hybridum, and Medicago lupulina. This information supports National Park Service policy against planting roadsides with exotics like Poa pratensis (Kentucky bluegrass), Phleum pratensis (timothy), Agropyron cristatum (crested wheatgrass), Bromus inermis (smooth brome), Dactylis glomerata (orchard grass), and most clovers Trifoliums. Some little sampled species (e.g. Erphorbia escula and Chrysanthemum leucanthemum) are expanding rapidly and are more noxious than Table 2 suggests.

Second, when planning control measures, one asks which exotics are likely to interfere with roadside plantings and which might be ignored. Plants likely to be important in each type are indicated by high cover $(C>1 \%, D>2 \%, E>5 \%$, $\mathrm{F}>25 \%$ ) in the environments where they can dominate. The restorer can use this data to determine which seed impurities to avoid and which seedlings may require special control.

Third, to the extent that upper populations of exotics are less well developed than those of natives, we may expect high altitude populations to eventually become more troublesome. The change may be based on further introductions, better distribution upward from low altitude populations, or on development of high altitude ecotypes. The hypothesis underlying the ecotype statement is that exotics were originally (pre-) adapted to low altitude sites, were introduced there, and are developing ecotypes that allow them to move upward (Chabot and Billings 1972). Inter-contentional and interstate quarantine should reduce invasion. Inter-altitudinal quarantine, for example thorough cleaning of machinery, horses, and hikers before moving from low to high altitude sites may slow the development of high altitude ecotypes.

Fourth, on non-park sites some exotic annuals, for example the smaller mustards, may be acceptable as nurse crops.

\section{$\checkmark \quad$ Literature Cited}

Chabot, B. and D Billings. 1972. Origins and ecology of the Sierra alpine flora and vegetation. Ecological Monographs 42: 163-199.

Daubenmire, R. 1968. Plant communities. Harper and Row, NY. 300 pgs. 
Daubenmire, R. \& J. 1968. Forest vegetation of eastern Washington and $\mathrm{N}$ Idaho. Wash Ag Expt Sta Tech Bull 60., Pullman. 104 pgs.

Daubenmire, R. 1970. Steppe vegetation of Washington. Wash Ag Expt Sta Tech Bull 62, Pullman. 131 pgs.

Dickie, J., K. Gajjar, P. Birch, and J. Harris. 1988. Survival of viable seeds in stored topsoil from opencast coal workings and its implications for site restoration. Biol Conservation 267-265.

Dittberner, P. and M. Olson. 1983. The plant information network (PIN) data base: Colorado, Montana, N Dakota, Utah, and Wyoming. US Fish and Wildlife Service FWS/OBS-83/36. 786 pgs.

Heslop, Harrison J. 1964. Forty years of genecology. Adv Ecol Research 2: 159-248.

McCaughey, W., W. Schmidt, and R. Shearer. 1986. Seed dispersal characteristics of conifers in the inland mountain west. pgs 50-62 IN R Shearer ed. 1986 Conifer tree seed in the inland mountain west. USDA Forest Service Gen Tech Rept INT 203, 289 pgs.

Mueggler, W. and W. Stewart. 1980. Grassland and shrubland habitat types of western Montana. USDA Forest Service Gen Tech Rept INT-66. 154 pgs.

Munshower, F. 1994. Practical handbook of disturbed land reclamation. CRC Press. Boca Raton, Florida. 265 pgs.

Pfister, R., B. Kovalchik, S. Arno and R. Presby. 1977. Forest habitat types of Montana. USDA Forest Service Gen Tech Rept INT34. Ogden. 174 pgs.
Schmidt, W. and J. Lotan. 1980. Phenology of common forest flora of the northern Rockies -- 1928 to 1937. USDA Forest Service Research Paper INT- 259. Ogden UT. 20 pgs.

Steele, R., S. Cooper, D. Ondov, D. Roberts and R. Pfister. 1983. Forest habitat types of eastern Idaho and western Wyoming. USDA Forest Service Gen Tech Report INT 144, Ogden UT. 144 pgs.

Weaver, T. 1979. Changes in soils along a vegetational (attitudinal) gradient of the northern Rocky Mountains. p14-29 IN: C. Youngberg ed. 1979. Proc. of the Fifth North American Forest Soils conf., Soil Science Soc. Amer., Madison, WI.

Weaver, T. 1980. Climates of vegetation types of the northern Rocky Mountains and adjacent plains. American Midland Naturalist 103: 392-398.

Weaver, T., D. Gustafson, J. Lichthardt, and B. Woods. 1989. Distribution of exotic plants in the northern Rocky Mountains by environmental type and disturbance condition. MSU Biology Report \#41, Montana State University, Bozeman. 91 pgs.

Weaver, T. 1994. Vegetation distribution and production in Rocky Mountain climates-with emphasis on whitebark pine. 11 pgs IN W. Schmidt and K. Holtmeier eds. 1994. Stone pines and their environments: the status of our knowledge. USDA Forest Service Gen Tech Rept INT-XXX. Proceedings of an international workshop 511 Sept 1992, San Moritz Switzerland. 
Table 2. Natives colonizing roadcuts in fifteen Rocky Mountain environmental types (HTs). All species with constancies greater than $50 \%$ in

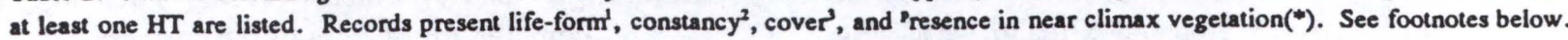

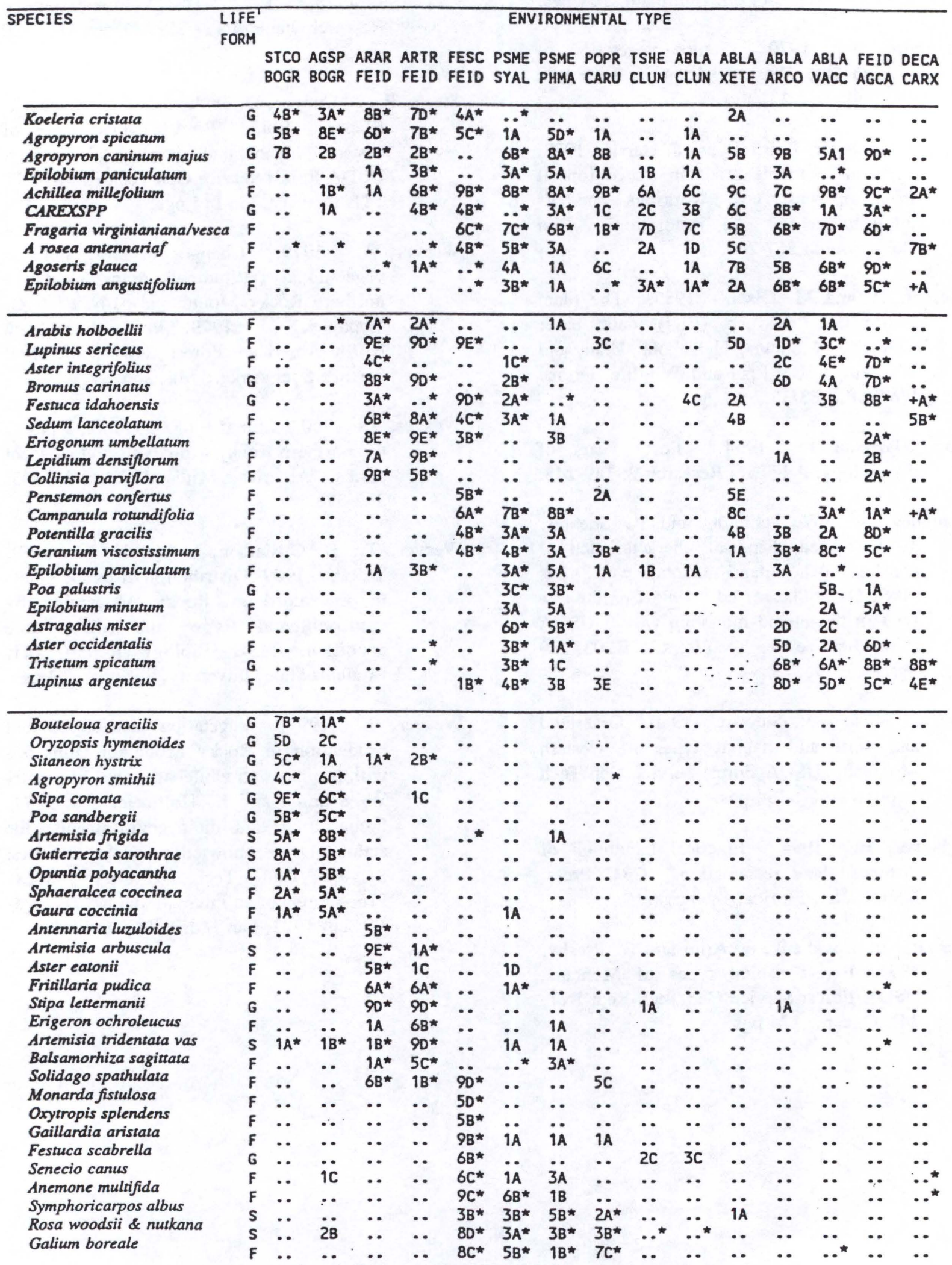


Aster modestus

Pseudotsuga menziesii

Solidago missouriensis

Hieracium cynoglossoides

Prunus virginiana

Populus tremuloides

Vicia americana

Hieracium albiflorum

Castilleja miniata

Anaphalis margaritacea

Aster laevis

Abies lasiocarpa

Pinus contorta

Pinus contorta

Potentilla argentea

Agrostis scabra

Solidago multiradiata

Hordeum brachyantherum

Deschampsia caespitosa

Androsace septentrionalis

Poa alpina

Festuca ovina

Carex scopulorum

Potentilla diversifolia

Artemisia scopulorum

Polygonum bistortoides

Arenaria obtusiloba

Luzula spicata

Geum rossii

Erigeron simplex

Poa grayana

Microseris cuspidata

Sibbaldia procumbens

Draba incerta

Carex phaeocephala
Valeriana dioica

Solidago canadensis

Picea engelmannii

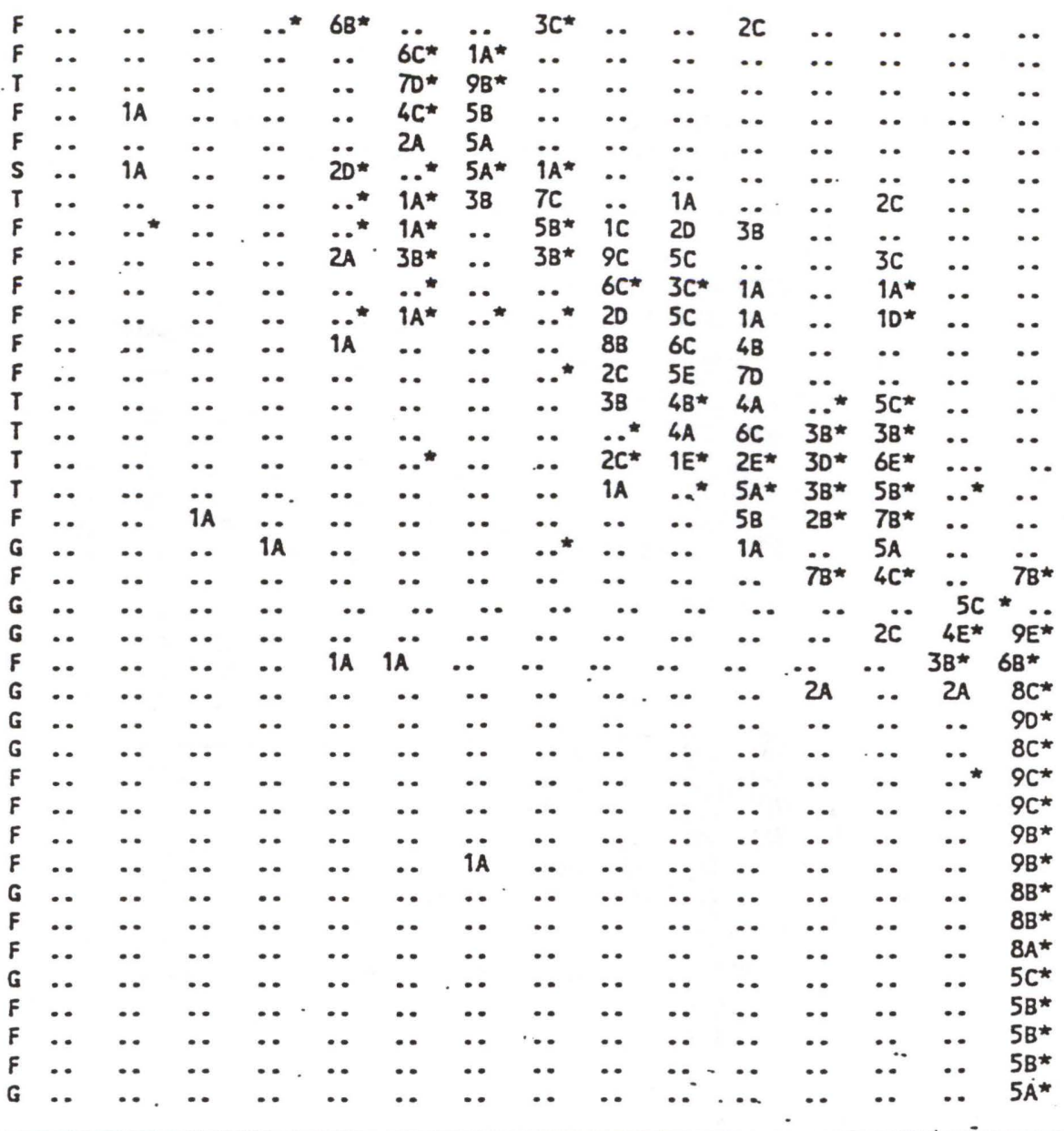

1 Life forms are $T=$ tree, $S=$ shrub, $G=$ grass, and $F=$ forb.

2 Constancies (=prob stand presence) are $0=0-9 \%, 1=10-19 \%, \ldots .9=90-100 \%$

3 Cover classes are $\mathrm{A}=0, \mathrm{~B}<1 \%, \mathrm{C}<2 \%, \mathrm{D}<5 \%, \mathrm{E}<25 \%, \mathrm{~F}<100 \%$.

4 An asterisk indicates that the species alsò appears in late seral vegetation; no asterisk indicates absence. 
Table 3. Exotics colonizing roadcuts in fifteen Rocky Mountain environments (HTs). All species with constancies greater than $50 \%$ in at least on HT are listed. Records present life-form ${ }^{1}$, constancy ${ }^{2}$, cover', and Presence in near climax vegetation ("). See footnotes below.

\begin{tabular}{|c|c|c|c|c|c|c|c|c|c|c|c|c|c|c|c|c|}
\hline \multirow[t]{2}{*}{ SPECIES } & \multirow{2}{*}{$\begin{array}{l}\text { LIFE } \\
\text { FORM }\end{array}$} & \multicolumn{14}{|c|}{ ENVIRONMENTAL TYPE } & \multirow{2}{*}{$\begin{array}{l}\text { DECA } \\
\text { A CARX }\end{array}$} \\
\hline & & $\begin{array}{l}\text { STCO } \\
\text { BOGR }\end{array}$ & $\begin{array}{l}\text { SP } \\
\text { GR }\end{array}$ & $\begin{array}{l}\text { ARAR } \\
\text { FEID }\end{array}$ & $\begin{array}{l}\text { ARTR } \\
\text { FEID }\end{array}$ & $\begin{array}{l}\text { FESC } \\
\text { FEID }\end{array}$ & $\begin{array}{l}\text { PSME } \\
\text { SYAL }\end{array}$ & $\begin{array}{l}\text { PSME } \\
\text { PHMA }\end{array}$ & $\begin{array}{l}\text { POPR } \\
\text { CARU }\end{array}$ & $\begin{array}{l}\text { TSHE } \\
\text { CLUN }\end{array}$ & $\begin{array}{l}\text { ABLA } \\
\text { CLUN }\end{array}$ & $\begin{array}{l}\text { ABLA } \\
\text { XETE }\end{array}$ & $\begin{array}{l}\text { ABLA } \\
=\text { ARCO }\end{array}$ & $\begin{array}{l}\text { ABLA } \\
\text { VACC }\end{array}$ & $\begin{array}{l}\text { FEID } \\
\text { AGCA }\end{array}$ & \\
\hline $\begin{array}{l}\text { Tragopogon dubious } \\
\text { Centaurea maculosa } \\
\text { Melilotus officinalis } \\
\text { Poa compressa } \\
\text { Bromus inemis } \\
\text { Poa pratensis } \\
\text { Dactylis glomerata } \\
\text { Taraxacum officinale } \\
\text { Phleum pratense } \\
\text { Trifolium repens } \\
\text { Trifolium hybridum }\end{array}$ & $\begin{array}{l}\mathbf{F} \\
\mathbf{F} \\
\mathbf{F} \\
\mathbf{G} \\
\mathbf{G} \\
\mathbf{G} \\
\mathbf{G} \\
\mathbf{F} \\
\mathbf{G} \\
\mathbf{F} \\
\mathbf{F}\end{array}$ & $\begin{array}{l}4 A^{*} \\
4 B^{*} \\
8 B^{*} \\
1 A \\
2 B \\
4 E^{*} \\
\cdots \\
\ldots \\
\cdots \\
\cdots \\
\cdots\end{array}$ & $\begin{array}{l}8 A^{\star} \\
3 A^{\star} \\
88^{\star} \\
1 A \\
5 E \\
5 E^{\star} \\
\ddot{2 A} \\
\cdots \\
\cdots \\
\cdots\end{array}$ & $\begin{array}{l}1 A^{\star} \\
10 \\
\cdots \\
\ddot{2 B} \\
9 E^{\star} \\
2 B \\
\ddot{i A}^{\star} \\
\cdots \\
\cdots\end{array}$ & $\begin{array}{l}5 B^{\star} \\
\cdots \\
\cdots \\
\cdots \\
9 E^{\star} \\
3 B \\
5 B^{\star} \\
\cdots \\
\cdots \\
\cdots\end{array}$ & $\begin{array}{l}4 A^{\star} \\
7 E^{\star} \\
6 B^{\star} \\
6 C^{\star} \\
50 \\
80^{\star} \\
3 B^{*} \\
90^{\star} \\
\ddot{2 A}\end{array}$ & $\begin{array}{l}2 A \\
2 A \\
3 B \\
1 A^{\star} \\
50^{\star} \\
7 C^{\star} \\
2 B^{\star} \\
8 C^{\star} \\
7 C^{\star} \\
50^{\star} \\
1 A^{\star}\end{array}$ & $\begin{array}{l}5 B^{\star} \\
30 \\
5 A \\
1 A \\
8 B \\
6 C^{\star} \\
5 E^{\star} \\
88^{\star} \\
80^{\star} \\
1 A \\
\cdots\end{array}$ & $\begin{array}{l}1 A \\
7 C \\
9 C^{\star} \\
8 C \\
2 A^{\star} \\
7 B^{\star} \\
\ddot{8 B^{\star}} \\
9 E^{\star} \\
\ddot{2 C}\end{array}$ & $\begin{array}{l}1 A \\
2 B \\
2 A \\
1 A \\
5 E \\
4 B \\
1 A \\
9 C \\
90 \\
8 C \\
90\end{array}$ & $\begin{array}{l}2 B \\
\ddot{1 B} \\
1 A \\
8 E \\
6 C \\
\ddot{8 C} \\
9 C \\
4 B \\
80\end{array}$ & $\begin{array}{l}\ddot{\cdots} \\
\ddot{1 A} \\
3 \mathrm{~A} \\
6 \mathrm{~B} \\
7 \mathrm{~B} \\
1 \mathrm{~A} \\
5 \mathrm{C} \\
9 \mathrm{C} \\
8 \mathrm{~B} \\
60\end{array}$ & $\begin{array}{l}1 B \\
\ldots \\
\ddot{1 A} \\
70 \\
5 C \\
1 B \\
9 E \\
8 B \\
1 B \\
8 E\end{array}$ & $\begin{array}{l}1 A \\
\ddot{3 E} \\
\ddot{40} \\
4 C \\
2 B \\
80 \\
8 C \\
4 B \\
8 E\end{array}$ & $\begin{array}{l}\ddot{x} \\
\ddot{1 B^{*}} \\
1 A \\
\ddot{70^{*}} \\
\ddot{9 C^{\star}} \\
7 B^{\star} \\
1 C \\
6 C\end{array}$ & 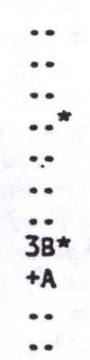 \\
\hline $\begin{array}{l}\text { Lactuca serriola } \\
\text { Verbascum thapsus } \\
\text { Bromus tectorum } \\
\text { Descurainia pinnata } \\
\text { Polygonum aviculare } \\
\text { Madia glomerata } \\
\text { Medicago lupulina }\end{array}$ & $\begin{array}{l}F \\
F \\
G \\
F \\
F \\
F \\
F\end{array}$ & $\begin{array}{l}5 A^{\star} \\
2 A^{\star} \\
9 B^{\star} \\
5 A^{\star} \\
\cdots \\
\cdots \\
\cdots\end{array}$ & $\begin{array}{l}2 B^{\star} \\
1 A^{\star} \\
7 D^{\star} \\
5 A^{\star} \\
1 A \\
\cdots \\
\cdots\end{array}$ & 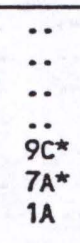 & $\begin{array}{l}2 A \\
\cdots \\
\cdots \\
4 B^{\star} \\
5 C^{\star} \\
\cdots\end{array}$ & $\begin{array}{l}\ddot{2 B} \\
\ldots \\
\cdots \\
\cdots \\
\cdots\end{array}$ & $\begin{array}{l}1 A \\
\cdots \\
\cdots \\
\ddot{1 A} \\
4 \mathrm{C}\end{array}$ & $\begin{array}{l}5 A \\
5 B \\
3 B^{\star} \\
\cdots \\
\ddot{6 C} \\
\ddot{6}\end{array}$ & $\begin{array}{c}\ddot{1 A} \\
\ldots \\
\ddot{3 B} \\
\ddot{0}\end{array}$ & $\begin{array}{l}\cdots \\
\cdots \\
\cdots \\
\cdots \\
\cdots \\
\cdots\end{array}$ & $\begin{array}{l}\cdots \\
\cdots \\
\cdots \\
\cdots \\
\cdots \\
\cdots\end{array}$ & $\begin{array}{l}\cdots \\
\cdots \\
\cdots \\
\cdots \\
\cdots \\
\cdots\end{array}$ & 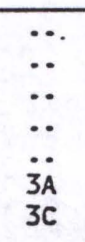 & $\begin{array}{l}\cdots \\
\cdots \\
\cdots \\
4 B \\
4 B\end{array}$ & $\begin{array}{l}\ddot{ } \\
\ddot{2} \\
\ddot{2} \\
\ddot{2}{ }^{\star} \\
3 A\end{array}$ & $\begin{array}{l}\ddot{ } \\
\ddot{0} \\
\ddot{0} \\
\cdots \\
\cdots\end{array}$ \\
\hline $\begin{array}{l}\text { Agropyron cristatum } \\
\text { Alyssum alyssoides } \\
\text { Camelina microcarpa } \\
\text { Bromus japonicus } \\
\text { Rumex acetosa/acetosll } \\
\text { Cirsium arvense } \\
\text { Festuca pratensis } \\
\text { Trifolium procumbens } \\
\text { Trifolium pratense } \\
\text { Trifolium repens } \\
\text { Trifolium hybridum } \\
\text { Agrostis alba } \\
\text { Chrysanthemum leucanth }\end{array}$ & $\begin{array}{l}G \\
F \\
F \\
G \\
F \\
F \\
G \\
F \\
F \\
F \\
F \\
G \\
F\end{array}$ & $\begin{array}{l}7 C^{\star} \\
8 A^{\star} \\
4 A^{\star} \\
8 B^{\star} \\
\cdots \\
\cdots \\
\cdots \\
\cdots \\
\cdots \\
\cdots \\
\cdots \\
\cdots\end{array}$ & $\begin{array}{l}\ddot{9 B}^{\star} \\
5 A^{\star} \\
6 A^{\star} \\
\ddot{1 A} \\
\cdots \\
\cdots \\
\cdots \\
\cdots \\
\cdots \\
\cdots\end{array}$ & $\begin{array}{l}\ddot{ } \\
\ddot{ } \\
\ddot{90} \\
\cdots \\
\cdots \\
\cdots \\
\cdots \\
\cdots \\
\cdots\end{array}$ & 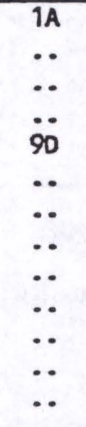 & 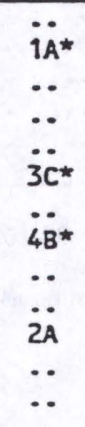 & $\begin{array}{l}\because \because \\
\ddot{1 A} \\
1 A \\
1 A \\
4 A \\
1 A \\
\ddot{5 B^{\star}} \\
5 D^{\star} \\
1 A^{\star} \\
1 A \\
\cdots\end{array}$ & $\begin{array}{l}\ddot{1 A} \\
\ddot{\cdots} \\
\ddot{1 A} \\
5 A \\
\ddot{1 A} \\
\hat{P A}^{*} \\
\cdots \\
\cdots\end{array}$ & 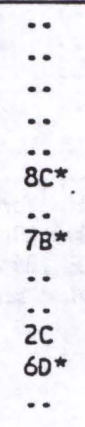 & $\begin{array}{l}\ddot{0} \\
\ddot{0} \\
\ddot{1 C} \\
\ddot{.} \\
\ddot{.} \\
\ddot{7 C} \\
70 \\
8 C \\
90 \\
6 C \\
5 B\end{array}$ & $\begin{array}{l}\ldots \\
\ldots \\
\ldots \\
\ldots \\
\ldots \\
50 \\
10 \\
48 \\
80 \\
4 A \\
\ldots\end{array}$ & $\begin{array}{l}\cdots \\
\cdots \\
\ddot{1 A} \\
\therefore \\
\because \\
\ddot{3 B} \\
80 \\
88 \\
60 \\
58 \\
\cdots\end{array}$ & 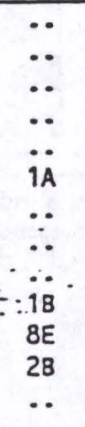 & $\begin{array}{l}\because \\
\cdots \\
\cdots \\
\cdots \\
\cdots \\
\cdots \\
\because \\
4 B \\
8 E \\
48 \\
\cdots\end{array}$ & 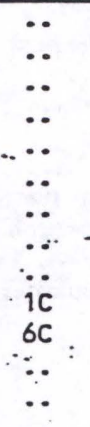 & 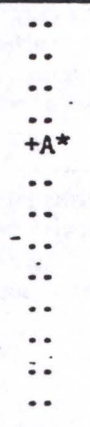 \\
\hline
\end{tabular}

1 Life forms are $T=$ tree, $S=$ shrub, $G=$ grass, and $F=$ forb.

2 Constancies (=prob stand presence) are $0=0-9 \%, 1=10-19 \%, \ldots .9=90-100 \%$

3 Cover classes are $\mathrm{A}=0, \mathrm{~B}<1 \%, \mathrm{C}<2 \%, \mathrm{D}<5 \%, \mathrm{E}<25 \%, \mathrm{~F}<100 \%$.

4 An asterisk indicates that the species also appears in late seral vegetation; no asterisk indicates absence. 